\title{
Penguatan Budaya Literasi di Pesantren
}

\author{
Abu Maskur \\ Universitas Indrapraprasta PGRI Jakarta, Indonesia \\ masykur_azizi@yahoo.co.id
}

\begin{abstract}
Abstrak:
Pondok pesantren merupakan lembaga pendidikan Islam tertua di Indonesia. Kitab kuning yang menjadi kurikulum wajib merupakan akar budaya literasi di pondok pesantren. Perkembangan teknologi dan informasi menjadi salah satu sebab menurunnya minat baca-tulis di masyarakat Indonesia, termasuk kalangan pondok pesantren. Dengan demikian, penguatan budaya literasi di pondok pesantren perlu dilakukan.
\end{abstract}

Kata Kunci: Budaya Literasi, Pesantren, Pendidikan Islam

\begin{abstract}
:
Islamic boarding school is the oldest Islamic education institution in Indonesia. The yellow book which is a compulsory curriculum is the root of literacy culture in Islamic boarding schools. The development of technology and information is one of the reasons for the decline in literacy in Indonesian society, including in Islamic boarding schools. Thus, strengthening the literacy culture in Islamic boarding schools needs to be done.
\end{abstract}

Keyword: Literacy Culture, Pesantren, Islamic Education

\section{Pendahuluan}

Pondok pesantren merupakan sebuah lembaga pendidikan Islam tertua di Indonesia. Kehadirannya telah memberikan pengaruh yang sangat penting bagi keberlangsungan hidup bangsa Indonesia khususnya umat Islam di Indonesia. Pondok pesantren telah melahirkan banyak tokoh yang tidak hanya disegani di dalam negeri saja tetapi juga di dunia internasional seperti Syeikh Ahmad Khatib Al-Minangkabawi, Syeikh Yasin bin Isa Al-Fadani, Syeikh Nawawi Al-Bantani, Syeikh Mahfudhz At-Tirmasi, dan tokoh-tokoh lainnya yang kesemuanya itu adalah dididik di pondok pesantren. Ketokohan beliau-beliau selain karena ilmunya sangat luas juga karena mereka banyak menghasilkan karya, Syeikh Ahmad Khatib Al-Minangkabawi 
dengan salah satu kitabnya Hasyiyah An-Nafahat 'ala Syarhil Waraqat lii Mahalli, Syeikh Yasin Al-Fadani dengan salah satu kitabnya Jam'ul Jawami, Syeikh Nawawi Al-Bantani dengan salah satu kitabnya Tafsir Al-Munir, dan Syeikh Mahfudhz At-Tirmasi dengan salah satu kitabnya Al-Badru Al-Munir fi Qira'ati al-Imam Ibnu Katsir. Keberhasilan mereka untuk menghasilkan banyak karya disebabkan karena mereka sudah terbiasa untuk membaca dan menulis sehingga menjadi bagian yang tidak terpisahkan dalam hidupnya atau dalam hal ini bisa kita sebut bahwa budaya literasi telah mengakar kuat dalam kehidupannya.

Secara sederhana, budaya literasi dapat didefinisikan sebagai kemampuan menulis dan membaca masyarakat dalam suatu negara. ${ }^{1}$ Masalah literasi masih menjadi isu yang sangat menarik untuk didiskusikan, termasuk bagi kalangan pondok pesantren mengingat saat ini budaya membaca dan menulis yang notabene ciri khasnya di kalangan pondok pesantren sedang mengalami kemunduran. Kemunduran ini disebabkan salah satunya oleh kemajuan teknologi dan informasi. Dampak positif kemajuan teknologi dan informasi bagi kalangan pondok pesantren adalah mudahnya bagi kalangan pondok pesantren untuk mencari sumber belajar atau literatur-literatur keislaman yang dibutuhkan dengan mengakses internet secara mudah dan murah. Selain memberikan dampak positif tersebut, kemajuan teknologi dan informasi juga memberikan dampak negatif bagi keberlangsungan literasi di pondok pesantren, yakni malasnya bagi kalangan pondok pesantren untuk membaca terlebih lagi menulis padahal dua hal tersebut adalah tradisi khasnya pondok pesantren.

Dengan demikian dalam tulisan ini, penulis akan membahas tentang pentingnya penguatan budaya literasi bagi kalangan pondok pesantren yang tujuannya adalah memberi pemahaman bahwa budaya literasi itu sangat penting bagi keberlangsungan pondok pesantren, yakni meningkatkan kualitas pondok pesantren dalam rangka mewujudkan pondok pesantren sebagai pusat literasi.

\section{Budaya Literasi Dan Pondok Pesantren}

\section{Pengertian Budaya}

Kata "Budaya" berasal dari Bahasa Sanskerta "Buddhayah", yakni bentuk jamak dari "Buddhi" (akal). Jadi, budaya adalah segala hal yang bersangkutan dengan akal. Selain itu kata budaya juga berarti "budi dan daya" atau daya dari budi. Jadi budaya adalah segala daya dari

\footnotetext{
${ }^{1}$ Suwardi Endaswara, Strategi Pengembangan Budaya Literasi Sastra Di Sekolah dan Masyarakat, Prosiding Seminar Nasional Bahasa dan Sastra Universitas Muhammadiyah Malang, 2017, hal. 413.
} 
budi, yakni cipta, rasa dan karsa. ${ }^{2}$ Sedangkan menurut Kamus Besar Bahasa Indonesia, budaya artinya pikiran, akal budi, hasil, adat istiadat atau sesuatu yang sudah menjadi kebiasaan yang sukar diubah. ${ }^{3}$ Jadi dapat disimpulkan bahwa budaya segala sesuatu hasil dari cipta, rasa dan karsa yang sudah menjadi kebiasaan yang sukar diubah.

\section{Pengertian Literasi}

Istilah literasi pada umumnya mengacu pada keterampilan membaca dan menulis, artinya seorang literat adalah orang yang telah menguasai keterampilan membaca dan menulis dalam suatu bahasa, namun demikian pada umumnya keterampilan membaca seseorang itu lebih baik daripada kemampuan menulisnya, bahkan kemampuan atau keterampilan berbahasa lainnya yang mendahului kedua keterampilan tersebut dari sudut kemudahannya dan penguasaannya adalah kemampuan menyimak dan berbicara. ${ }^{4}$

Istilah literasi berasal dari Bahasa Latin literatus yang berarti "a learned person" atau orang yang belajar. Pada abad pertengahan, seorang literatus adalah orang yang dapat membaca, menulis, dan bercakap-cakap dalam Bahasa Latin. Pada perkembangan selanjutnya, kemampuan literasi tidak hanya terbatas pada kemampuan membaca, tapi juga menulis. ${ }^{5}$

Menurut Kern, sebagaimana dikutip oleh Bahrul Hayat dan Suhendra Yusuf, literasi secara sempit didefinisikan sebagai kemampuan membaca dan menulis, termasuk di dalamnya pembiasaan membaca dan mengapresiasi karya sastra serta melakukan penilaian terhadapnya. Sedangkan secara luas, Kern mendefinisikan literasi sebagai kemampuan untuk berpikir dan belajar seumur hidup untuk bertahan dalam lingkungan sosial dan budaya. Mc Kenn dan Robinson menyatakan bahwa literasi merupakan suatu media bagi individu agar mampu berinteraksi dengan lingkungan sosialnya, terutama berkaitan dengan kemampuan menulis. ${ }^{6}$

Membaca pada hakikatnya adalah suatu kegiatan yang rumit yang melibatkan banyak hal, dalam membaca tidak hanya sekedar melafalkan tulisan, akan tetapi juga melibatkan aktivitas visual, berpikir, psikolinguistik, dan metokognitif. Sebagai proses visual, membaca

${ }^{2}$ Ary H. Gunawan, Sosiologi Pendidikan: Suatu Analisis Sosiologi Tentang Pelbagai Problem Pendidikan, (Jakarta: Rineka Cipta: 2000), hal. 16.

${ }^{3}$ Departemen Pendidikan Nasional, Kamus Besar Bahasa Indonesia Edisi Ke-III, (Jakarta: 2000), hal. 169.

${ }^{4}$ Lizamudin Ma’mur, Membangun Budaya Literasi, (Jakarta: Diadit Media, 2010), hal. 111.

${ }^{5}$ Singgih D. Gunarsa, Bunga Rampai Psikologi Perkembangan Dari Anak Sampai Usia Lanjut, (Jakarta: Gunung Mulia, 2006), hal. 44.

${ }^{6}$ Bahrul Hayat dan Suhendra Yusuf, Benchmark Internasional Mutu Pendidikan, (Jakarta: Bumi Aksara, 2010), hal. 25. 
yaitu proses menerjemahkan simbol tulis (huruf) ke dalam kata-kata lisan. Sebagai proses berpikir, membaca mencakup aktivitas pengenalan kata, pemahaman literal, interpretasi, membaca kritis dan pemahaman kreatif. ${ }^{7}$ Sedangkan menulis ialah menurunkan atau melukiskan lambang-lambang grafik yang menggambarkan suatu bahasa yang dipahami oleh seseorang sehingga orang lain dapat membaca lambang-lambang grafik tersebut yang di dalamnya mengandung pesan yang dibawa penulis. Pesan yang dibawa oleh penulis melalui gambar huruf-huruf disebut karangan. Karangan sebagai ekspresi pikiran, gagasan, pendapat, pengalaman disusun secara sistematis dan logis. ${ }^{8}$ Membaca dan menulis adalah dua hal yang sangat erat kaitannya. Seseorang yang akan menulis maka tentu dia akan melakukan kegiatan membaca terlebih dahulu meskipun kegiatan membaca tidak harus diikuti dengan kegiatan menulis. Jadi secara sederhana dapat disimpulkan bahwa literasi adalah kemampuan seseorang dalam membaca dan menulis.

\section{Pengertian Pondok Pesantren}

Secara Bahasa, pondok pesantren terdiri dari dua kata, yaitu "pondok" dan "pesantren. Istilah "pondok" menurut Zamakhsyari Dhofier berasal dari Bahasa Arab فندوق (dibaca: funduq) yang berarti penginapan, asrama atau wisma sederhana, karena pondok memang sebagai tempat penampungan sederhana dari para pelajar/santri yang jauh dari tempat asalnya. ${ }^{9}$ Sedangkan istilah "pesantren" berasal dari kata "santri" yang mendapat awalan "pe-“ dan akhiran"-an" sehingga menjadi kata pesantrian atau pesantren.

Adapun asal-usul kata "santri” menurut Nurcholis Madjid ada dua pendapat. Pertama, pendapat yang mengatakan bahwa "santri" berasal dari perkataan "sastri", sebuah kata dari Bahasa Sanskerta yang artinya melek huruf. Kedua, pendapat yang mengatakan bahwa perkataan santri sesungguhnya berasal dari Bahasa Jawa, dari kata "cantrik", berarti seseorang yang selalu mengikuti seorang guru kemana guru pergi menetap. ${ }^{10}$ Dengan demikian dapat disimpulkan bahwa pondok pesantren adalah tempat atau lembaga pendidikan Islam bagi para santri yang ingin belajar tentang Islam.

${ }^{7}$ Farida Rahim, Pengajaran Membaca Di Sekolah Dasar, (Jakarta: Bumi Aksara, 2008), hal. 2.

${ }^{8}$ Sutari, Dasar-dasar Kemampuan Menulis, (Bandung: FPBS IKIP, 1997), hal. 26.

${ }^{9}$ Zamakhsyari Dhofier, Tradisi Pesantren: Studi Tentang Pandangan Hidup Kyai, (Jakarta: LP3ES, 1982), hal. 18. $19-20$.

${ }^{10}$ Nurcholis Madjid, Bilik-Bilik Pesantren: Sebuah Potret Perjalanan, (Jakarta: Paramadina, 1997), hal. 
Dari beberapa pengertian istilah di atas dapat disimpulkan bahwa budaya literasi pondok pesantren adalah proses pembiasaan membaca dan menulis di lingkungan pondok pesantren.

\section{Literasi Dalam Alquran}

Alquran adalah kalam Allah yang bersifat mu'jizat yang diturunkan kepada Nabi Muhammad SAW melalui perantara Jibril dengan lafal dan maknanya dari Allah SWT, yang dinukilkan secara mutawatir, membacanya merupakan ibadah; dimulai dengan surah AlFatihah dan diakhiri dengan surah An-Nas. ${ }^{11}$ Alquran bagi umat Islam adalah sebagai petunjuk hidup baik petunjuk hidup di dunia terlebih lagi petunjuk hidup di akhirat kelak. Secara global, Alquran mengatur segala tindak-tanduk kehidupan manusia mulai dari hal-hal yang sederhana sampai ke hal-hal yang rumit, dari hal-hal yang kecil sampai ke hal-hal yang besar termasuk dalam hal ini Alquran juga memberikan gambaran tentang perintah kepada manusia untuk selalu membaca dan menulis atau yang disebut dengan istilah literasi.

Dalam Alquran terdapat banyak istilah yang bermakna membaca, baik secara hakiki maupun majazi, istilah-istilah yang menunjukkan makna membaca tersebut dalam Alquran di antaranya adalah kata qara'a (نر أ), tilawah (تلاون), dan tartila (تلان). Adapun kata qara'a (قر أ) dalam berbagai bentuknya terdapat sebanyak 87 kali dan tersebar dalam 41 surat Alquran ${ }^{12}$. Sedangkan kata tilawah (تلاوة) dalam berbagai bentuknya terulang sebanyak 64 kali $^{13}$, sementara kata tartila hanya diulang 2 kali dalam Alquran ${ }^{14}$ seperti yang terdapat dalam surat Al-Furqan ayat 32 dan surat Al-Muzzammil ayat 4. Namun dari ketiga istilah tersebut yakni qara'a (ترأ), tilawah (تراوة), dan tartila (ترنيلا) sering diterjemahkan ke dalam Bahasa Indonesia dengan makna membaca, dari sini juga jelaslah bahwa membaca adalah perintah Alquran kepada manusia terlebih lagi kepada orang-orang yang beriman kepada-Nya. Maka dari itu membaca (literasi) merupakan simbol yang penting bagi kehidupan manusia, agar manusia memiliki kehidupan yang berwarna. Membaca dan literasi dapat menambah keilmuan dan pengetahuan yang baru sehingga mempermudah dalam kehidupan dengan banyak ilmu yang dimiliki. ${ }^{15}$.

\footnotetext{
${ }^{11}$ M. Quraish Shihab, et. all., Sejarah dan Ulumul Qur'an, (Jakarta: Pustaka Firdaus, 2008), hal. 13.

${ }^{12}$ Muhammad Fuad Abdul Al-Baqai, Al-Mu'jam al-Mufahras Li al-Fadz Alquran al-Karim, (Dar alKutub al-Misriyyah, $1364 \mathrm{H}$ ), hal. 539-540.

${ }^{13}$ Muhammad Fuad Abdul Al-Baqai, Al-Mu'jam al-Mufahras Li al-Fadz Alquran al-Karim, hal. 155.

${ }^{14}$ Muhammad Fuad Abdul Al-Baqai, Al-Mu'jam al-Mufahras Li al-Fadz Alquran al-Karim, hal. 300.

${ }^{15}$ Asma Hasan Fahmi, Sejarah dan Filsafat Pendidikan terj. Hasan Ibrahim, (Jakarta: Bulan Bintang, 1979), hal. 107.
} 
Dalam Alquran, perintah membaca tersebut secara khusus bisa kita lihat pada lima ayat yang pertama kali turun, yaitu surat Al-'Alaq 1-5:

"Bacalah dengan (menyebut) nama Tuhanmu yang menciptakan. Dia telah menciptakan manusia dari segumpal darah. Bacalah, dan Tuhanmulah Yang Maha Mulia. Yang mengajar (manusia) dengan pena. Dia mengajarkan manusia apa yang tidak diketahuinya.” (QS. Al-`Alaq: 1-5).

Muhammad Ali As-Shabuni menjelaskan dalam kitabnya Shafwa at-Tafsir terkait ayat pertama surat Al-'Alaq ini bahwa ayat ini merupakan khitab Allah yang ditampakkan pertama kali dalam wahyu kepada Nabi. Tujuan ayat ini berindikasi sebagai ajakan untuk membaca, menulis, dan belajar. Karena semua kegiatan tersebut adalah syiar-syiar agama Islam. Pada kata yang pertama kali berindikasi permulaan perintah kepada Nabi dengan harapan agar Nabi mengetahui Dzat yang telah menciptakan seluruh makhluk hidup dan Dzat yang menjadikan semseta alam. Di dalam perintah tersebut mengandung makna yang mendalam, yaitu memohon pertolongan kepada Allah dengan menyebut nama Allah Yang Maha Agung. ${ }^{16}$ Yusuf Qardhawi mengungkapkan bahwa ayat pertama yang diturunkan kepada Rasulullah SAW merupakan petunjuk akan keutamaan belajar dan ilmu pengetahuan. Perintah membaca merupakan kunci ilmu pengetahuan dan alat untuk mentransformasikannya menggunakan qalam. ${ }^{17} \mathrm{Jadi}$, dalam ayat ini Allah Swt memerintahkan kepada manusia agar senantiasa membaca, baik terhadap ayat-ayat qauliyah (tersurat) yaitu Alquran maupun terhadap ayat-ayat kauniyah (tersirat) yaitu alam semesta dengan disertai penghambaan kepada Allah serta memohon pertolongan kepada Allah agar pembacaan tersebut menghasilkan sesuatu yang bermanfaat, baik bagi dirinya, orang lain dan lingkungan sekitarnya.

Dalam ayat kedua surat Al-‘Alaq dijelaskan bahwa Allah SWT menciptakan manusia dari bermula dari (علقة) atau zigot, yakni telur yang sudah dibuahi sperma yang sudah menempel di dinding rahim, kemudian pada proses selanjutnya berkembang menjadi manusia. Dari penciptaan manusia ini terkandung makna bahwa manusia dilihat dari asal-usulnya tidak ada artinya sehingga manusia tidak pantas untuk menyombongkan diri, selain itu ayat ini juga memberikan kesan terkait perintah membaca, yakni manusia diperintahkan untuk membaca tanda-tanda kekuasaan Allah melalui alam semesta atau yang dikenal dengan istilah ayat-ayat kauniyah yang dalam ayat ini ditunjukkan dengan penciptaan manusia.

\footnotetext{
${ }^{16}$ Muhammad Ali As-Shabuni, Shafwa at-Tafsir (Tafsir Alquran Al-Karim), (Beirut, Dar Alquran AlKarim, 1981), hal. 581.

${ }^{17}$ Yusuf Qardhawi, Alquran Berbicara Tentang Akal dan Ilmu Pengetahuan, (Jakarta: Gema Insani Press, 1998), hal. 91.
} 
Ayat ketiga surat Al-‘Alaq, Allah SWT kembali mengingatkan Nabi untuk membaca. Perbedaan perintah membaca pada ayat pertama dan ketiga ini adalah bahwa pada ayat pertama pembacaan harus disertai penghambaan diri kepada Allah SWT, sedangkan pada ayat ketiga menggambarkan manfaat yang diperoleh dari membaca, yakni Allah SWT akan menganugerahkan ilmu pengetahuan, pemahaman, dan wawasan baru sesuai janji dan Maha Pemurahnya Allah.

Selanjutnya, dalam ayat keempat Allah menjelaskan bagaimana cara-Nya mengajar, yakni dengan qalam. Bentuk pengajaran ini bersifat umum, artinya berlaku bagi manusia dan malaikat. Baru kemudian pada ayat selanjutnya diuraikan untuk pengajaran secara khusus pada insan atau manusia, yaitu mengajarkan apa-apa yang tidak diketahui sebelumnya. ${ }^{18}$ Allah bersumpah dengan atas nama qalam untuk menunjukkan bahwa qalam merupakan sesuatu yang sangat penting bagi kehidupan manusia. ${ }^{19}$ Pada ayat ini juga terkandung perintah untuk menulis yang disimbolkan dengan qalam sebagai alat untuk menulis.

Pada ayat kelima surat Al-'Alaq menjelaskan bahwa Allah lah yang merupakan sumber dari segala pengetahuan. Allah lah yang pertama kali mengenalkan kepada manusia namanama benda yang kemudian Allah memerintahkan kepada manusia mengamalkan terhadap sesuatu yang telah dimiliki, sehingga sesuatu tersebut menjadi sesuatu yang bermanfaat. ${ }^{20}$ Dan dengan qalam, Allah mengajarkan manusia tentang sesuatu yang belum mereka ketahui, mengeluarkan mereka dari kegelapan dan kebodohan, mengarahkan kepada cahaya ilmu pengetahuan, dan menyadarkan manusia akan akan nikmat-Nya yang tak ternilai harganya berupa pengetahuan tentang membaca dan menulis yang dengan keduanya dinamika ilmu pengetahuan berjalan secara kontinyu dan menyentuh segala sisi kehidupan umat manusia. ${ }^{21}$

Berdasarkan uraian di atas, secara konseptual dapat dikatakan bahwa literasi dalam Alquran terdapat dalam lima ayat pertama surat Al-'Alaq yang secara substansial berisi tentang perintah kepada manusia untuk belajar dengan cara membaca, baik membaca ayat-ayat qauliyah (Alquran) maupun ayat-ayat kauniyah (alam semesta), yang tujuannya tidak lain

\footnotetext{
${ }^{18}$ Yusuf Qardhawi, Alquran Berbicara Tentang Akal dan Ilmu Pengetahuan, hal. 92.

${ }^{19}$ Yusuf Qardhawi, Alquran Berbicara Tentang Akal dan Ilmu Pengetahuan, hal. 93.

${ }^{20}$ Muhammad Makki an-Nashiri, At-Taisir fi Ahaditsi at-Tafsir Juz 6, (Beirut: Dar al-Gharbal-Islami, 1985), hal. 446

${ }^{21}$ Moh. Roqib, Ilmu Pendidikan Islam: Pengembangan Pendidikan Integratif Di Sekolah, Keluarga Dan Masyarakat, (Yogyakarta: LKiS, 2009), hal. 1.
} 
dalam rangka merealisasikan tugasnya manusia sebagai hamba Allah dan khalifah di muka bumi.

Selain perintah membaca, Alquran juga memerintahkan manusia untuk menulis dalam arti seluas-luasnya yang disimbolkan dengan istilah qalam. Dalam ayat kempat dan kelima surat Al-'Alaq disinggung tentang istilah qalam, dimana ayat keempat menjelaskan bahwa Allah SWT mengajarkan kepada manusia dengan qalam dan pada ayat kelima menjelaskan Allah SWT mengajarkan manusia sesuatu yang belum ia (manusia) ketahui melalui qalamNya. Selain terdapat dalam surat Al-'Alaq khususnya ayat keempat dan kelima, perintah menulis juga terdapat dalam surat Al-Qalam yang merupakan rangkaian surat yang pertama kali turun kepada Nabi SAW.

Dalam surat Al-Qalam ayat kedua Allah bersumpah dengan menggunakan qalam. Ketika Allah bersumpah dengan suatu ciptaan-Nya maka sesuatu itu luar biasa atau sesuatu itu harus menjadi perhatian serius bagi orang-orang yang mengimani kitab-Nya, termasuk dalam hal ini Allah bersumpah dengan qalam. Hamka dalam tafsir Al-Azhar menjelaskan bahwa kata qalam yang bermakna pena dalam ayat tersebut merupakan kunci pembuka ilmunya Allah. Tuhan telah mentakdirkan bahwa pena merupakan alat untuk mencatat ilmu pengetahuan. Dengan pena yang digunakan untuk menulis, manusia dapat belajar dan memahami berbagai hal yang tidak diketahui sebelumnya. Tentang ayat ini, Hamka juga mengutip pernyataan Syaikh Muhammad Abduh yang menyatakan bahwa ayat ini merupakan ayat yang memiliki makna begitu mendalam tentang betapa pentingnya membaca dan menulis ilmu pengetahuan dalam berbagai cabangnya ${ }^{22}$.

Dari uraian di atas dapat disimpulkan bahwa membaca dan menulis adalah perintah Allah SWT, bahkan perintah tersebut terdapat pada surat-surat yang pertama kali turun kepada Nabi Muhammad SAW, yaitu surat Al-'Alaq ayat 1-5 dan surat Al-Qalam ayat 2. Dengan demikian, Al-Quran sangat mendorong umat manusia khusunya orang beriman untuk senantiasa membudayakan dan memperkuat tradisi literasi dalam kehidupannya.

\section{Kitab Kuning Sebagai Akar Budaya Literasi Pondok Pesantren}

Secara umum, tumbuhnya literasi dalam Islam salah satunya dapat dilihat dari upaya mengabadikan Al-Quran dengan cara menuliskannya yang dimulai sejak masa Nabi Muhammad SAW, meskipun pada waktu itu baca tulis belum membudaya di kalangan bangsa

\footnotetext{
${ }^{22}$ Hamka, Tafsir Al-Azhar, (Jakarta: Pustaka Panjimas, 2005), hal. 211.
} 
Arab. Tradisi masyarakat pada masa itu didominasi oleh tradisi lisan. Masyarakat Arab memiliki tradisi menghafalkan syair-syair, puisi-puisi, termasuk garis keturunan mereka. Tradisi tersebut diwariskan secara turun temurun secara lisan, sehingga kemampuan membaca dan menulis bukan sesuatu yang penting. Pada masa itu, mayoritas masyarakat tidak dapat membaca dan menulis. Barulah kemudian pada masa permulaan Nabi Muhammad SAW mengajarkan Islam di Mekah, telah muncul beberapa orang yang pandai baca tulis seperti Umar bin Khattab, Ali bin Abi Thalib, Usman bin Affan, Muawiyah bin Abu Sufyan dan lain-lain. ${ }^{23}$

Dengan diangkatnya Nabi Muhammad SAW sebagai rasul yang ditandai dengan turunya wahyu pertama di Gua Hira, maka kemudian Nabi Muhammad SAW. mengganti kebiasaan tersebut dengan membaca Al-Quran. Setiap kali wahyu turun, Nabi Muhammad SAW menyampaikan wahyu tersebut kepada para sahabat dan memerintahkan mereka untuk membaca dan menghafalnya, sehingga membaca Al-Quran menjadi tradisi dalam kehidupan mereka menggantikan kebiasaan membaca syair-syair. ${ }^{24}$ Di samping itu, penulisan Al-Qur'an yang terjadi pada masa Rasulullah SAW selain yang diperintahkan oleh Rasulullah SAW juga masih berupa catatan-catatan pribadi para sahabat dan tersebar pada lembaran-lembaran, tulang-tulang, pelepah kurma, dan lain sebagainya. Ini menunjukkan bahwa Nabi Muhammad SAW melakukan perubahan peradaban yang semula hanya terbatas pada peradaban melalui hafalan menjadi peradaban melalui bacaan dan tulisan. Berkat pembaharuan perabadaban yang dilakukan oleh Rasulullah tersebut yang disertai semakin menguatnya pengaruh Islam, Islam mampu mengambil alih kendali kebudayaan dan peradaban dunia yang semula berpusat di Mesopotamia, Yunani, Cina, India, Persia, Romawi, dan Arkandia menjadi peradaban dunia yang berdasarkan pada nilai-nilai Al-Qur'an dan hadits berpusat di Madinah, Damaskus, Baghdad, dan Andalusia. Dengan demikian, dapat dikatakan bahwa peradaban suatu bangsa dapat dibangun dengan memperkuat tradisi literasi, yakni tradisi membaca dan menulis sebagaimana Rasulullah SAW membangun perdaban masyarakat Arab.

Tradisi literasi umat Islam Indonesia khususnya kalangan pesantren sudah mengakar kuat, tradisi literasi tersebut adalah kitab kuning. Bagi kalangan pesantren, istilah kitab kuning bukanlah istilah asing melainkan merupakan identitas dirinya yang membedakan dengan lembaga pendidikan lainnya, bahkan bisa dikatakan bahwa suatu lembaga pendidikan tidak bisa disebut pesantren jika di dalamnya tidak mengkaji kitab kuning.

\footnotetext{
${ }^{23}$ Zuhairini dkk., Sejarah Pendidikan Islam, (Jakarta: Bumi Aksara, 2010), hal. 28.

${ }^{24}$ Zuhairini dkk, Sejarah Pendidikan Islam, hal. 26.
} 
Secara umum kitab kuning dipahami sebagai kitab-kitab keagamaan berbahasa Arab, menggunakan aksara Arab yang dihasilkan oleh para ulama dan para pemikir muslim lainnya, terutama dari Timur Tengah. Bahkan Azyumardi Azra menambahkan bahwa kitab kuning tidak hanya menggunakan Bahasa Arab, akan tetapi juga bahasa lokal (daerah), seperti: Melayu, Jawa, dan bahasa lokal lainnya di Indonesia dengan menggunakan aksara Arab. Dengan demikian, selain ditulis oleh para ulama Timur Tengah juga ditulis oleh para ulama Indonesia sendiri ${ }^{25}$. Kitab kuning juga dapat diartikan dengan kitab yang berisi ilmu-ilmu keislaman, fiqh khususnya, yang ditulis atau dicetak dalam Bahasa Arab/Melayu/Jawa/Sunda dan sebagainya tanpa memakai harakat/syakal (tanda baca/baris) ${ }^{26}$. Menurut Abdullah Aly, dalam dunia pesantren, posisi kitab kuning sangat strategis karena kitab kuning dijadikan sebagai tex book, references, dan kurikulum dalam sistem pendidikan pesantren. Selain sebagai pedoman bagi tatacara keberagamaan, kitab kuning difungsikan juga oleh kalangan pesantren sebagai referensi universal dalam menyikapi segala tantangan kehidupan ${ }^{27}$.

Secara historis, Ali Yafie mengatakan bahwa istilah kitab kuning pada beberapa puluh tahun terakhir ini belum dikenal, sebab dunia pesantren pada saat itu menutup diri dari dunia luar, terutama dari arus kebudayaan asing (baca: Barat), sebagai satu sikap oposisi diam (silent opposition) terhadap penjajah Belanda. Oleh karena itu, dunia pesantren tidak mengenal adanya buku-buku di luar kitab kuning. ${ }^{28}$ Menurut Martin Van Bruinessen, kitab kuning sebagai kitab klasik berbahasa Arab telah dikenal dan dipelajari pada abad ke-16. Argumen yang dijadikan dasar adalah dibawanya sejumlah naskah Indonesia yang berbahasa Arab, Melayu, dan Jawa ke Eropa sekitar tahun 1600 M. ${ }^{29}$ Selanjutnya Azyumardi Azra sebagaimana mengutip hasil penelitian Van Der Berg, menjelakan bahwa kitab kuning baru muncul di Indonesia abad ke-17. Menurutnya, kitab kuning, seperti kitab Taqrib karya Abu Suja' alIsfahani (w. 593H/1196 M) kemudian menyusul berturut-turut al-Muharrar karya Abu Qashim al-Rafi'I (w. 623 H/1226 M) dan seterusnya, dibawa ke Indonesia oleh para murid Jawi yang belajar di Haramain ketika kembali pulang ke tanah air. Pada abad ke-17 inilah semakin banyak pelajar Jawi yang belajar di tanah suci. Setelah menamatkan pelajaranya, kemudian kembali

\footnotetext{
${ }^{25}$ Azyumardi Azra, Pendidikan Islam: Tradisi dan Modernisasi Menuju Milenium Baru, (Jakarta: Logos, 1999), hal. 111

${ }^{26}$ Ensiklopedi Hukum Islam III, (Jakarta: Ichtiar Baru Van Hoeve, cet. II, 1999), hal. 950.

${ }^{27}$ Abullah Aly, Pendidikan Multikultural di Pesantren, (Yogyakarta: Pustaka Pelajar,2011), hal. 185.

${ }^{28}$ Ali Yafie, Kitab Kuning: Produk Peradaban, dalam Jurnal Pesantren, No. I, Vol. VI, 1989, hal. 3.

${ }^{29}$ Martin Van Bruinessen, Kitab Kuning: Pesantren dan Tarekat, (Bandung: Mizan, 1999), hal. 27.
} 
ke tanah air mereka membawa kitab-kitab yang dikajinya, dan selanjutnya mengedarkannya di lingkungan terbatas yang dapat membaca dan memahami bahasa Arab. ${ }^{30}$

Selanjutnya kitab kuning menemukan momentumnya pada abad ke-19, ketika kitab kuning dijadikan sebagai materi pokok pengajaran di pondok pesantren, meunasah, atau istilah lainnya. Kondisi tersebut didukung oleh sikap dan semangat perlawanan secara diam terhadap kolonialisme Belanda atau anti penjajahan, yang pada akhirnya ikut berperan dalam membentuk sikap menutup diri terhadap budaya asing atau Barat dalam menggunakan literatur atau sebagai bahan rujukan. Dari sinilah awal mulanya kitab kuning dijadikan sebagai rujukan pokok dan kurikulum di pondok pesantren.

Pelestarian pengajaran kitab kuning di pesantren telah berjalan terus-menerus, dan secara kultural telah menjadi ciri khusus pesantren sampai saat ini. Di sini peran lembaga pesantren dalam meneruskan tradisi keilmuan klasik sangatlah besar ${ }^{31}$, yang kemudian membentuk kultur keislaman yang khas yang berbeda dengan kultur keislaman lain. Dengan demikian dapat disimpulkan bahwa kitab kuning merupakan akar tradisi literasi pondok pesantren.

\section{Penguatan Budaya Literasi Di Pondok Pesantren}

Ada beberapa unsur yang perlu dikembangkan dalam rangka penguatan budaya literasi di pondok pesantren, di antaranya adalah sebagai berikut:

\section{Pengembangan Perpustakaan Pondok Pesantren}

Secara umum perpustakaan mempunyai arti sebagai suatu tempat yang di dalamnya terdapat kegiatan perhimpunan, pengolahan, dan penyebarluasan (pelayanan) segala macam informasi, baik yang tercetak maupun yang terekam dalam berbagai media seperti buku, majalah, surat kabar, film, kaset, tape recorder, video, komputer, dan lain-lain. Semua koleksi sumber informasi tersebut disusun berdasarkan sistem tertentu dan dipergunakan untuk kepentingan belajar melalui kegiatan membaca dan mencari informasi bagi segenap masyarakat yang membutuhkannya. ${ }^{32}$ Perpustakaan bagi kalangan pondok pesantren belum mendapatkan perhatian yang serius, hal ini dibuktikan dengan keberadaannya di pondok

\footnotetext{
${ }^{30}$ Azyumardi Azra, Pendidikan Islam: Tradisi dan Modernisasi Menuju Milenium Baru, hal. 112-113.

${ }^{31}$ Yasmadi, Modernisasi Pesantren, (Ciputat: Ciputat Press, 2005), hal. 90.

${ }^{32}$ Pawit M. Yusuf \& Yahya Suhendar, Pedoman Penyelenggaraan Perpustakaan Sekolah, (Jakarta: Kencana, 2005), hal. 1.
} 
pesantren. Hampir di setiap pondok pesantren tidak memiliki perpustakaan jikapun ada mungkin kondisinya sangat memprihatinkan, padahal perpustakaan merupakan jantungnya lembaga pendidikan termasuk pondok pesantren, bahkan secara historis kemajuan peradaban Islam didorong oleh keberadaan perpustakaan, dan perpustakaan yang terkenal dalam sejarah Islam adalah Baitul Hikmah, yang didirikan oleh Khalifah Al-Ma'mun dari dinasti Abbasiyah tahun 318 H. Dengan demikian, agar terwujudnya budaya literasi di pondok pesantren, maka hal pertama yang perlu dikembangkan adalah keberadaan perpustakaan yang up to date, rapi, bersih, nyaman dan sejuk, serta memiliki fasilitas yang lengkap agar menarik minat bagi kalangan pesantren.

\section{Koleksi Buku atau Kitab}

Koleksi dapat didefinisikan sebagai sebagai sebuah bahan perpustakaan atau sejenisnya yang dikumpulkan, dikelola, dan diolah dengan kriteria tertentu. Sedangkan buku menurut UNESCO sebagaimana dikutip Wiji Suwarno menyatakan bahwa buku merupakan informasi tercetak yang diterbitkan dan dipublikasikan dengan jumlah minimal 49 halaman tidak termasuk daftar isi dan halaman sampul. ${ }^{33}$ Jadi koleksi buku adalah salah satu bahan perpustakaan yang dikumpulkan, dikelola, diolah, dan digunakan untuk memenuhi kebutuhan informasi pengguna perpustakaan.

Koleksi buku atau kitab juga merupakan unsur terpenting bagi terwujudnya budaya literasi di pondok pesantren. Koleksi buku atau kitab yang ada di pondok pesantren diharapkan dapat mencukupi kebutuhan bagi warga pesantren. Jika koleksi buku atau kitab lengkap maka akan memudahkan bagi kalangan santri untuk mencari referensi atau sekedar menambah wawasan sehingga meningkatkan minat baca bagi kalangan pesantren, sebaliknya jika koleksi buku atau kitab tidak lengkap atau minim maka kalangan pesantren akan malas untuk berkunjung ke perpustakaan. Pengembangan atau penambahan koleksi buku atau kitab tersebut bisa dilakukan dengan cara membeli buku secara langsung ke toko buku atau kitab, pemesanan lewat penerbit, hibah/hadiah, atau bahkan sumbangan dari para alumni, pemerintah setempat, perusahaan, dan lain sebagainya.

${ }^{33}$ Wiji Suwarno, Perpustakaan dan Buku: Wacana Penulisan dan Penerbitan, (Yogyakarta: Ar-Ruz Media, 2011), hal. 59. 


\section{Pembiasaan Membaca dan Menulis}

Membaca merupakan kegiatan yang sangat penting bagi siapa saja, terlebih bagi kalangan pondok pesantren. Membaca dapat membawa seseorang kepada tujuan-tujuan yang diinginkannya, karena dengan membaca selain dapat menambah wawasan dan pengetahuan seseorang, juga dapat mengembangkan kreativitas, dan apresiasi dalam kehidupan sepanjang hayatnya. Oleh karena itu minat membaca harus terus dikembangkan, khususnya di pondok pesantren.

Pondok pesantren sejak lama telah mengajarkan dan membudayakan minat baca-tulis, karena para santri setiap hari wajib membaca kitab-kitab kuning serta memberikan catatancatatan terhadap kitab yang dibacakan oleh kyai atau ustadz, yang pada tahap selanjutnya para santri akan diminta untuk membacakannya di hadapan kyai atau ustadz. Walaupun tradisi bacatulis sudah menjadi kebiasaan bagi kalangan pesantren, namun tidak jarang kita jumpai bahwa para santri banyak membaca hanya sekedar untuk memenuhi kewajiban yang telah dibebankan oleh kyai atau ustadznya sehingga tradisi baca-tulis belum menjadi sebuah kebutuhan, untuk mengatasi hal tersebut bisa dilakukan dengan cara memberikan kebebasan kepada para santri untuk memilih buku atau kitab yang disukainya, membiasakan para santri untuk membaca buku, serta menyampaikan pendapat tentang buku yang telah dibacanya. Dengan demikian selain dapat meningkatkan kreativitas, juga dapat meningkatkan kepercayaan diri bagi para santri. Sedangkan untuk mengembangkan tradisi menulis bisa dilakukan dengan cara mengadakan pelatihan jurnalistik, penulisan karya ilmiah, bedah buku, atau kegiatan lainnya yang terkait dengan kepenulisan.

\section{Kesimpulan}

Budaya literasi pondok pesantren adalah proses pembiasaan membaca dan menulis di lingkungan pondok pesantren. Budaya literasi tersebut merupakan perintah Al-Qur'an, sebagaimana yang terdapat dalam surat Al-'Alaq ayat 1-5 dan surat Al-Qalam ayat 2, bahkan Rasulullah SAW berhasil membangun peradaban dalam masyarakat Arab secara khusus dan peradaban umat Islam secara umum melalui budaya baca-tulis. Budaya baca-tulis ini kemudian berkembang pasca Rasulullah SAW wafat, yang ditandai dengan proses pembukuan Al-Qur'an dan pada masa selanjutnya budaya baca-tulis telah mendorong kejayaan Islam dengan peradabannya yang gemilang.

Budaya literasi umat Islam Indonesia khususnya kalangan pesantren, telah mengakar kuat, 
budaya literasi tersebut adalah kitab kuning. Kitab kuning adalah kitab-kitab keagamaan Islam berbahasa Arab, menggunakan aksara Arab yang dihasilkan oleh para ulama dan para pemikir muslim lainnya, terutama dari Timur Tengah, yang ditulis dalam kertas yang berwarna kuning. Kitab kuning merupakan materi pokok pondok pesantren sehingga pondok pesantren identik dengan kitab kuning, bahkan suatu lembaga pendidikan Islam tidak bisa disebut pondok pesantren jika di dalamnya tidak dikaji kitab kuning sehingga kitab kuning bisa disebut sebagai akar sejarah budaya literasi pondok pesantren. Ada beberapa unsur yang perlu dikembangkan dalam rangka penguatan budaya literasi di pondok pesantren, yaitu pengembangan perpustakaan, koleksi buku atau kitab, dan pembiasaan membaca dan menulis bagi kalangan pesantren. 


\section{Daftar Pustaka}

Abdul Al-Baqai, Muhammad Fuad. Al-Mu'jam al-Mufahras Li al-Fadz al-Qur'an alKarim, Dar al-Kutub al-Misriyyah, $1364 \mathrm{H}$.

Aly, Abdullah. Pendidikan Multikultural di Pesantren, Yogyakarta: Pustaka Pelajar, 2011.

An-Nashiri, Muhammad Makki. At-Taisir fi Ahaditsi at-Tafsir Juz 6, Beirut: Dar alGharbal-Islami, 1985.

As-Shabuni, Muhammad Ali. Shafwa at-Tafsir (Tafsir Al-Qur'an Al-Karim), Beirut: Dar Al-Qur'an Al-Karim, 1981.

Azra, Azyumardi. Pendidikan Islam: Tradisi dan Modernisasi Menuju Milenium Baru, Jakarta: Logos, 1999.

Bahrul Hayat dan Suhendra Yusuf. Benchmark Internasional Mutu Pendidikan, Jakarta: Bumi Aksara, 2010.

Dhofier, Zamakhsyari. Tradisi Pesantren: Studi Tentang Pandangan Hidup Kyai, Jakarta: LP3ES, 1982.

Endaswara, Suwandi. Strategi Pengembangan Budaya Literasi Sastra Di Sekolah dan Masyarakat, Prosiding Seminar Nasional Bahasa dan Sastra Universitas Muhammadiyah, Malang: 2017.

Ensiklopedi Hukum Islam III, Jakarta: Ichtiar Baru Van Hoeve, cet. II, 1999.

Fahmi, Asma Hasan. Sejarah dan Filsafat Pendidikan terj. Hasan Ibrahim, Jakarta: Bulan Bintang, 1979.

Gunarsa, Singgih D. Bunga Rampai Psikologi Perkembangan Dari Anak Sampai Usia Lanjut, Jakarta: Gunung Mulia, 2006.

Hamka. Tafsir Al-Azhar, Jakarta: Pustaka Panjimas, 2005.

Madjid, Nurcholis. Bilik-Bilik Pesantren: Sebuah Potret Perjalanan, Jakarta: Paramadina, 1997.

Pawit M. Yusuf \& Yahya Suhendar. Pedoman Penyelenggaraan Perpustakaan Sekolah, Jakarta: Kencana, 2005.

Qardhawi, Yusuf. Al-Qur'an Berbicara Tentang Akal dan Ilmu Pengetahuan, Jakarta: Gema Insani Press, 1998.

Rahim, Farida. Pengajaran Membaca Di Sekolah Dasar, Jakarta: Bumi Aksara, 2008.

Roqib, Moh. Ilmu Pendidikan Islam: Pengembangan Pendidikan Integratif Di Sekolah, Keluarga Dan Masyarakat, Yogyakarta: LKiS, 2009. 2008.

Shihab, M. Quraish, et. all., Sejarah dan Ulumul Qur'an, Jakarta: Pustaka Firdaus,

Sutari. Dasar-dasar Kemampuan Menulis, Bandung: FPBS IKIP, 1997. 
Abu Maskur

Suwarno, Wiji. Perpustakaan dan Buku: Wacana Penulisan dan Penerbitan, Yogyakarta: Ar-Ruz Media, 2011.

Van Bruinessen, Martin. Kitab Kuning: Pesantren dan Tarekat, Bandung: Mizan,1999.

Yafie, Ali. Kitab Kuning: Produk Peradaban, dalam Jurnal Pesantren, No. I, Vol. VI, 1989, hal. 3 .

Yasmadi. Modernisasi Pesantren, Ciputat: Ciputat Press, 2005, hal. 90.

Zuhairini dkk. Sejarah Pendidikan Islam, Jakarta: Bumi Aksara, 2010. 